\title{
AMAZONIAN VÁRZEA FORESTS: ADAPTIVE STRATEGIES OF TREES AS TOOLS FOR FOREST MANAGEMENT
}

\section{FLORESTAS INUNDABLES AMAZÓNICAS: ESTRATEGIAS ADAPTATIVAS DE LOS ÁRBOLES Y MANEJO}

\author{
Pia Parolin ${ }^{1}$, Florian Wittmann ${ }^{1}$, Jochen Schöngart ${ }^{1}$ and Maria Teresa F. Piedade ${ }^{2}$
}

\begin{abstract}
Amazonian várzea forests are characterized by a high diversity of species and adaptations against extended flooding. Waterlogging and submergence can last up to 210 days per year, with a water column of up to 6-7 m. The present paper gives an insight into the current knowledge of morpho-anatomical, phenological and physiological responses to flooding in várzea trees, into patterns of regeneration and seedling recruitment, and into differences found along the flooding gradient, and between populations of selected species. This knowledge may serve as a basic tool for forest management. The high selective logging already caused a substitution of timber species, with high damages in the remaining stands, calling for rigorous management plans. Since the regular inundation induces the formation of annual rings, and tree growth responds to the prolonged vegetation period with significantly wider ring widths in El Niño years as compared to neutral years, tree ring analysis can be used also for the development of models to predict tree growth and to determine minimum logging diameters and cutting cycles for timber species.
\end{abstract}

Keywords: Amazonia, tree ecophysiology, establishment, environmental gradients, productivity, speciation, tree-ring analysis, El Niño.

\section{Resumen}

Los bosques de várzea Amazónica se caracterizan por una alta diversidad de especies y adaptaciones a largos periodos de inundación que pueden durar hasta 210 días del año, con una columna de agua excediendo los 6-7 m. La presente publicación presenta una revisión del conocimiento actual sobre las respuestas morfo-anatómicas, fenológicas, y fisiológicas a las inundaciones, y los patrones de regeneración, no sólo a lo largo de la gradiente de inundación, sino además entre poblaciones de las especies. Este conocimiento puede servir de base para instrumentos de manejo forestal sostenible. La alta selección de árboles de corte ya está causando una sustitución de las especies de madera, con alto daño al resto de árboles en pie, lo cual requiere un riguroso plan de manejo.

Puesto que las inundaciones regulares inducen a la formación de anillos/aros anuales en los árboles de la zona de inundación, y el ancho de los anillos/aros está correlacionado con el pulso de inundación y con las variables climáticas, y en los años de El Niño el nivel máximo de inundación es significativamente más bajo, el análisis del aro de los árboles puede ser usado también para el desarrollo de modelos para predecir el crecimiento de los árboles y determinar los diámetros mínimos para el corte de los árboles y los ciclos de corte para las especies de madera.

Palabras clave: Amazonía, ecofisiología del árbol, establecimiento, gradiente ambiental, productividad, especiación, análisis de anillos del árbol, El Niño.

\section{Introduction}

Amazonian várzea forests are seasonal floodplains with a monomodal, predictable flood-pulse (Junk et al. 1989) and cover approximately $300.000 \mathrm{~km}^{2}$ along the main rivers in the Amazon basin (Figure 1A). Seasonal precipitation causes periodical inundations of the floodplains along the Amazon River. These periods of extended flooding can last as much as 210 days per year, with a water column of up to 6-7 $\mathrm{m}$. New sediment deposit can reach $0.3-1 \mathrm{~m}$ every year (Junk, 1989; Campbell et al. 1992) so that there is a high nutrient input into the ecosystem which consequently is highly productive (Figure 1B) and extremely dynamic, with strong erosion and new land formations (Figure 1C). Fine-coarse sediments, which are deposited primarily in oxbows with reduced water velocity, worsen the physical soil properties because of the increasing lack of oxygen at the root level (Wittmann, 2002). The monomodal flood pulse of the rivers causes drastic changes in the bioavailability of nutrients, oxygen levels, and concentrations of phytotoxins (Parolin et al. 2004). Despite these adverse growth conditions for trees caused by prolonged flooding, Amazonian floodplain forests are highly diverse, with several hundred tree species occurring there (Wittmann et al., 2002).

Trees are extremely adapted to the periodical floodings: for example, seed maturity and dispersal 
are closely linked to the high water period (Figure 2A), water and fish being the main agents of dispersal (Goulding, 1983).

Despite their size and importance for the human population of the Amazon basin, the ecology of the floodplain forests is still poorly understood. Present investigations aim at understanding the following questions:

- How do the trees survive in the floodplains, which adaptations do they have against flooding and submergence?

- How do they regenerate, which patterns can be found concerning seedling recruitment and regeneration along the flooding gradient?

- How diverse are the forests? How does vegetation composition and structure change along environmental gradients? How does population differentiation and speciation work in the floodplains?

- And finally: how can the forests be preserved, which options are there for sustainable management?

\section{Adaptations}

In a recent review, Parolin et al. (2004) describe the adaptations found in trees of Amazonian floodplains. Among these are adaptations such as the formation of adventitious roots (Figure 2B), suberinization of the roots which helps against radial oxygen loss (Figure 3, De Simone et al., 2002, 2003), and the postulation of photosynthetic activity under water (Schlüter et al., 1993). Root system and sediment deposition showed a close relationship, plank buttressing being more common on sites subjected to lower sediment rates (Wittmann \& Parolin, in press).

Depending on their respective sets of adaptations and growth strategies (Parolin et al., 2004), most species are restricted to specific areas with a determined pattern of flooding, sedimentation and soil texture, leading to a clear vegetation zonations along the flooding gradient (Figure 4).

\section{Seedling recruitment and regeneration}

In Amazonian floodplains, it is almost unavoidable that seedlings are submerged for a certain period, except if they establish in the upper parts of the inundation gradient and grow so fast to be able to maintain some leaves above the water surface. Two extreme strategies for seedling establishment were described for Amazonian floodplains (Figure 5, Parolin, 2002a): tolerance of prolonged submergence vs. escape from submergence. Measurements of height increase in relation to floodplain system and nutrient availability, height in the inundation gradient, and seed mass of common species indicated that the two hypothesized strategies enable efficient seedling establishment on different levels in the flooding gradient. Where submergence is unavoidable, on the lower sites in the flooding gradient, seedlings had significantly lower shoot extension than on the higher sites. Large and small seeds produced seedlings with high shoot elongation, enhancing the chances of nonsubmergence for the seedlings at high elevations. This pattern was evident also within the family of Fabaceae, taking into account the effect of relatedness among species. It is assumed that the zonation observed in Amazonian floodplains is closely linked to the flooding tolerance and establishment strategy of the seedlings.

\section{Diversity}

Despite the unfavourable conditions in these floodplains, the species number of angiosperm trees is very high. With With 30-150 species (Pires \& Koury, 1959; Balslev et al., 1987; Ayres, 1993; Worbes, 1997; Wittmann et al., 2002) species richness is clearly lower than in the adjacent Terra Firme, where 180-300 species ha ${ }^{-1}$ occur (Klinge \& Rodrigues, 1968; Prance et al., 1976; Gentry, 1986, 1992). Still, species richness is high when compared to other forests on earth.

All species from Amazonian floodplains originate from the adjacent Terra Firme forests or savannas (Kubitzki, 1989). They probably occupied the little flooded periphery of the floodplain before differentiating to adapted species. Within the floodplain forests, these species did not radiate species richness of the floodplains results exclusively from parallel immigration of pre-adapted species and subsequent specialization and differentiation.

\section{Population differentiation}

Different adaptations and survival strategies related to morpho-anatomical, phenological and physiological responses to flooding were not only found between species along the flooding gradient, but also between different populations within a species. Intraspecific comparisons of populations growing in floodplains and in non-flooded Terra Firme forests showed clear differences, although it has yet to be analysed whether these are of phenotypic or genotypic nature.

One typical species occurring both, in flooded várzea and non-flooded Terra Firme, is the Apocynaceae Himatanthus sucuuba. Clear differences were found in seedlings resulting from populatins of the várzea and the Terra Firme concerning seed germination and seedling survival to submergence (Ferreira, 2002; Ferreira et al., in press). Morphological and physiological differences were also found, e.g. in the amount and pathway of aerenchyma formation in the different populations (Ferreira, 2002). In waterlogged seedlings from Várzea aerenchyma was formed by a schizogen pattern, in those from Terra Firme by a lysogen pattern. 


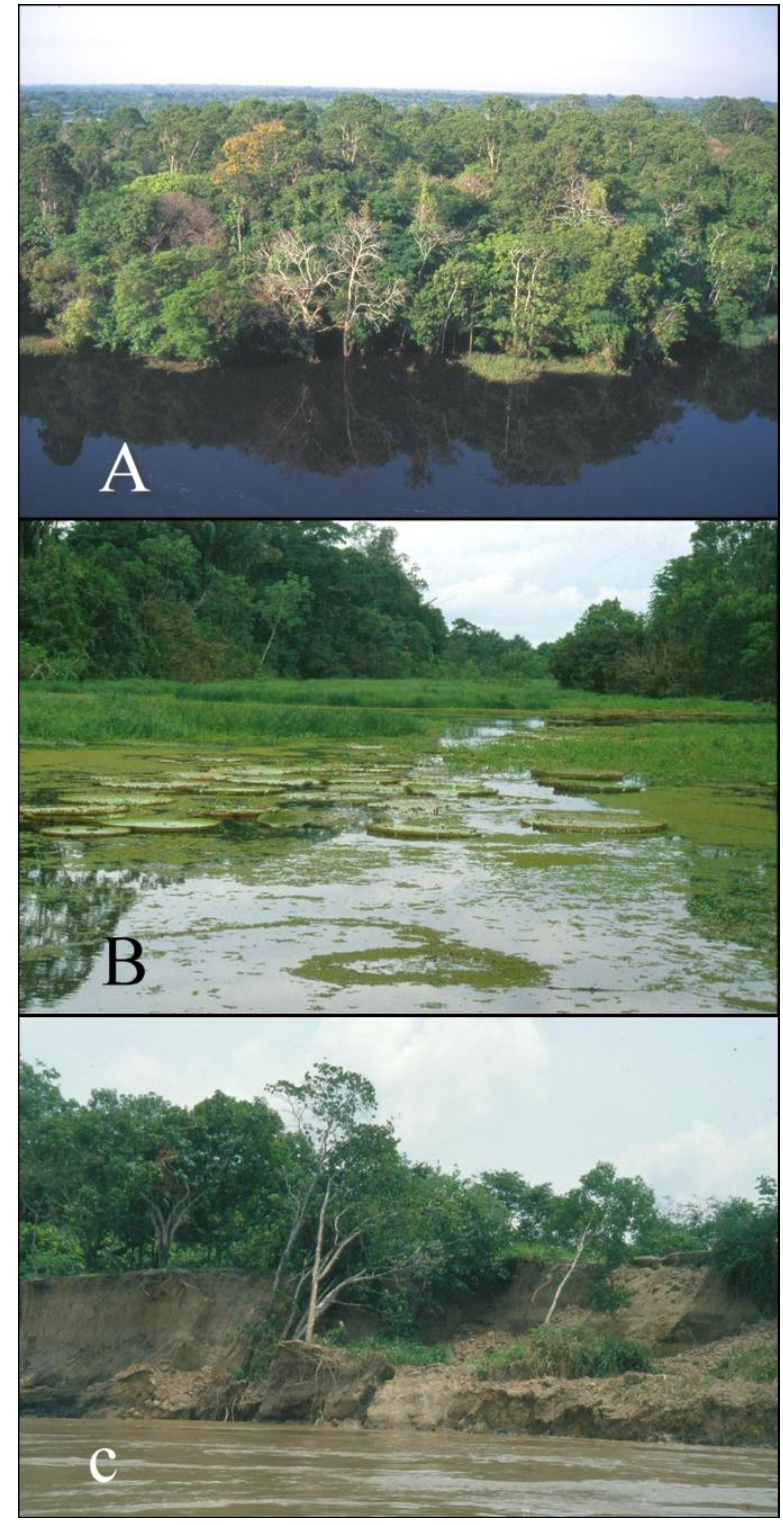

Figure 1. Amazonian várzea: A Forest at high water, $\mathrm{B}$ varzea with high productivity as shown by macrophyte growth, $\mathrm{C}$ erosion and land slides.

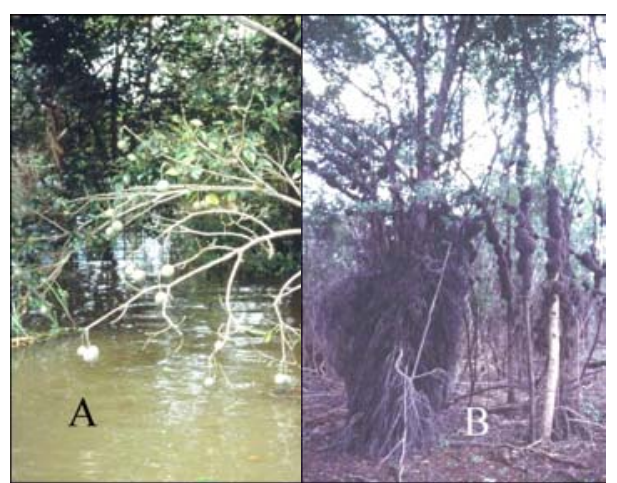

Figure 2. Adaptations to the periodical floodings: A Crateva benthami with mature fruits at high water, B adventitious roots in Calophyllum brasiliense in igapó.

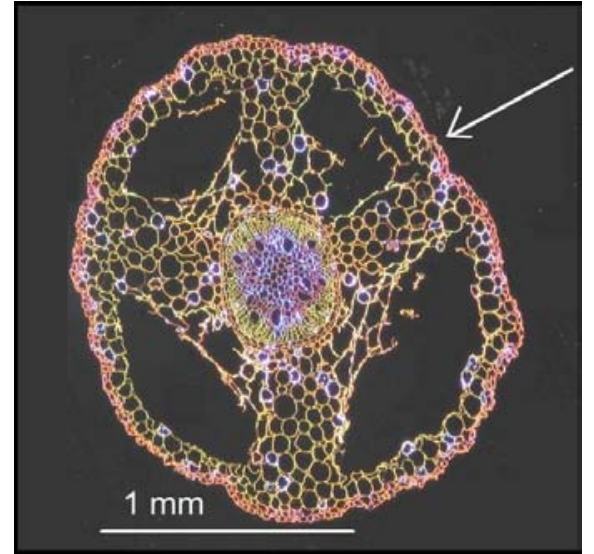

Figure 3. Root suberinization (arrow) against radial oxygen loss.

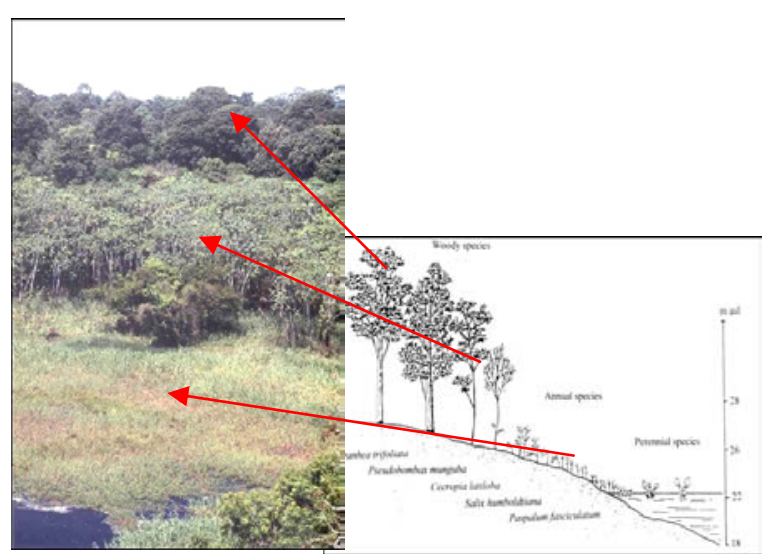

Figure 4. Vegetation zonation along the flooding gradient: scheme and photograph from the várzea near Manaus.

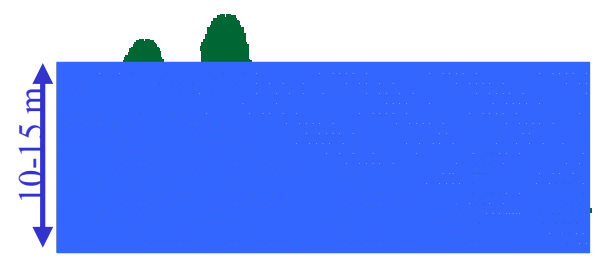

Figure 5. Scheme showing the flooding gradient and conditions for seedling establishment.

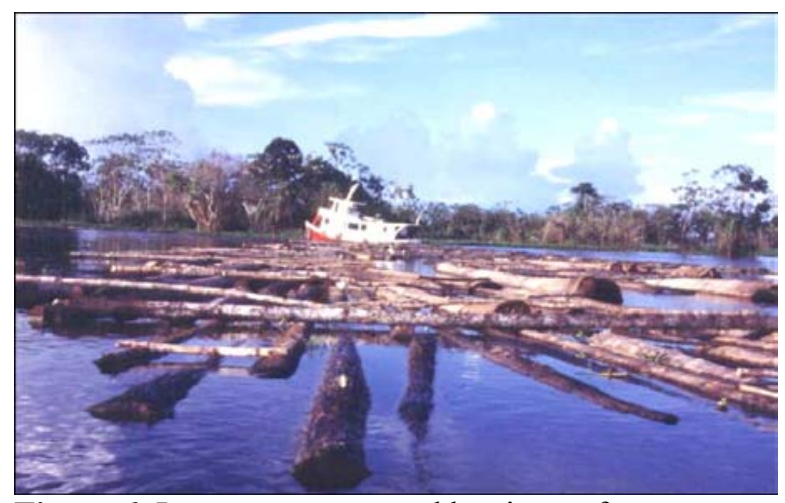

Figure 6. Logs are transported by river raft. 


\section{Tree ring analysis}

The regular inundation induces the formation of annual rings in trees of the flooded forests giving us the possibility to analyse annual growth increments and the relation of productivity and environmental factors (Schöngart et al., 2002; Schöngart et al., 2004). Tree ring widths correlate with the flood-pulse and related climate variables - e.g. El Niño events can be detected in tree-ring series and the variability and strength of the El Niño phenomenon can be reconstructed by dendrochronological techniques to pre-instrumental time periods (Schöngart, 2003a, b; Schöngart et al., 2004). In fact, there are weak but significant negative correlations between the ring widths and the amount of precipitation during the vegetation period (September-March), and a much stronger relation between tree growth and the floodpulse (Schöngart et al. 2004). Ring width correlates negatively with the length of the aquatic phase, the mean and maximum flood-level. The strongest climate-growth relationship can be detected between the ring width and the duration of the non-flooded period. In El Niño years, the maximum flood-level is significantly lower. Consequently the vegetation period in the floodplain forests is extended followed by a shortened aquatic phase. Tree growth responds to the prolonged vegetation period, with significantly wider ring widths in El Niño years as compared to neutral years.

Tree ring analysis is being used also for the development of models to predict tree growth and to determine minimum logging diameters and cutting cycles for timber species as an instrument for a forest management based on sustainability. The modelling of growth parameters permits the definition of specific management options for different timber species (Schöngart, $2003 \mathrm{a} \mathrm{b}$ ).

\section{Sustainable management}

Understanding the adaptive strategies of the trees is the basis for understanding their distribution, their ecological needs for survival and regeneration, and together with models of growth parameters we have a basis for management options and the conservation of commercially exploited tree species.

Within the Amazon basin, $60-90 \%$ of wood extraction occurs in the floodplains which is favoured by the low costs for logging, skidding and transport (Figure 6, Parolin, 2000). More than 50 tree species are used by locals, but only a few are commercially interesting. The easy accessibility and the high number of individuals of a species per area are advantageous. Natural resources like the production of oil, soap, resines, textile fibres, tannins, colours and medicines, aromas, latex, and fruits are of local and commercial importance (Parolin, 2002b). Timber is a very important good since 1900 , where it was used for energy production in steamboats, and for civil and naval construction.

Logging is done by hand or chainsaw, and the wood is transported by raft to Manaus where sawmills and timber industry are concentrated. Many commercially used tree species are threatened, especially in the vicinity of big cities. The high selective logging already caused a substitution of timber species, with high damages in the remaining stands, calling for rigorous management plans.

\section{Acknowledgments}

These studies were supported by the SHIFT program (BMBF/CNPq/IBAMA), project 14, 29-1, 29-2; BMBF: 0339685/LT0008; CNPq 690048/96-3; duration: 1991 - 2001, project leader: Prof. Dr. W. J. Junk, MPIL Plön.

\section{References}

Ayres J.M.C. 1993. As matas de várzea do Mamirauá. In: Estudos de Mamirauá. Sociedade Civil Mamirauá (ed.). Vol. I pp. 1-123. Brasília, DF.

Balslev H., Luteyn J., Oellgaard B. \& Holm-Nielsen L.B. 1987. Composition and structure of adjacent unflooded and floodplain forest in Amazonian Ecuador. Opera Bot. 92: 37-57.

Campbell D.G., Stone J.L. \& Rosas A. 1992. A comparison of the phytosociology and dynamics of three floodplain (Várzea) forests of known ages, Rio Juruá, Western Brazilian Amazon. Bot. J. Linnean Soc. 108: 213-237.

De Simone O., Haase K., Müller E., Junk W.J. \& Schmidt W. 2002. Adaptations of Central Amazon tree species to prolonged flooding: root morphology and leaf longevity. Plant Biol. 2: 515522.

De Simone O., Haase K., Müller E., Junk W.J., Hartmann K., Schreiber L. \& Schmidt W. 2003. Apoplasmic barriers and oxygen transport properties of hypodermal cell walls in roots from four Amazonian tree species. Plant Physiol. 132: 206-217.

Ferreira C.S. 2002. Germinação e adaptações metabólicas e morfo-anatômicas em plântulas de Himatanthus succuuba (Spruce) Wood., de ambientes de várzea e terra firme na Amazônia Central. Unpubl. Master-Thesis, Universidade do Amazonas (UA), Instituto Nacional de Pesquisas da Amazônia (INPA). Manaus.

Ferreira C.S., M.T.F. Piedade., Parolin P. \& Batista K.M.N. (in press): Adaptação ao estresse por alagamento da espécie amazônica Himatanthus sucuuba: germinação e desenvolvimento de plântulas. Acta Botanica Brasilica.

Gentry A.H. 1986. Endemism in tropical versus temperate plant communities. In: The Science of scarcity and diversity. Soul M.E. (ed.) Conservation Biology: The Science of Scarcity 
and Diversity. Sunderland, Massachusetts: Sinauer Associates, Inc. : 153-181.

Gentry A.H. 1992. Tropical forest biodiversity distributional patterns and their conservational significance. Oikos 63(1): 19-28.

Goulding M. 1983. The role of fishes in seed dispersal and plant distribution in Amazonian floodplain ecosystems. Sonderbd. Naturwiss. Ver. Hamburg 7: $271-283$.

Junk W.J. 1989. Flood tolerance and tree distribution in Central Amazonian floodplains. In: Tropical forests: Botanical dynamics, speciation and diversity. Eds. L.B. Nielsen, I.C. Nielsen \& H. Balslev. Academic Press London. : 47-64.

Junk W.J., Bayley P.B. \& Sparks R.E. 1989. The flood pulse concept in river-floodplain systems. In: Proceedings of the International Large River Symposium. Dodge D.P. (ed.). Can. Publ. Fish. Aquat. Sci. 106: 110-127.

Klinge H. \& Rodrigues W. 1968. Litter production in an area of Amazonian terra firme forest. Part I. Litterfall, organic and total nitrogen contents of litter. Amazoniana 1: 287-302.

Kubitzki K. 1989. The ecogeographical differentiation of Amazonian inundation forests. Plant Syst. Evol. 162: 285-304.

Parolin P. 2000. Growth, productivity and use of trees in white water floodplains. In: Junk, W.J., Ohly, J., Piedade, M.T.F. \& Soares, M.G. (eds.): The Central Amazon Floodplain: Actual Use and Options for a Sustainable Management. Backhuys Publishers b.V., Leiden. : 375-391.

Parolin P., De Simone O., Haase K., Waldhoff D., Rottenberger S., Kuhn U., Kesselmeier J., Schmidt W., Piedade M.T.F. \& Junk W.J. 2004. Central Amazon floodplain forests: tree survival in a pulsing system.- The Botanical Review 70(3): 357-380

Parolin P. 2002a. Submergence tolerance vs. escape from submergence: two strategies of seedling establishment in Amazonian floodplains. Environmental and Experimental Botany 48: 177186.

Parolin P. 2002b. Bosques inundados en la Amazonia Central: $\mathrm{Su}$ aprovechamiento actual y potencial.Revista de Ecología Aplicada. 1(1): 111-114

Pires J.M. \& H.M. Koury 1959. Estudo de um trecho de mata de várzea próximo a Belém. Boletim Goeldi 36: 3-44.
Prance G.T., Rodrigues W.A. \& da Silva M.F. 1976. Inventário florestal de um hectare de mata de terra firme $\mathrm{km} 30$ da estrada Manaus-Itacoatiara. Acta Amazonica 6(1): 9-35.

Schlüter U.B., Furch B. \& Joly C.A. 1993. Physiological and anatomical adaptations by young Astrocaryum jauari Mart. (Arecaceae) in periodically inundated biotopes of Central Amazonia. Biotropica 25(4): 384-396.

Schöngart J. 2003a. Biomass increment, dynamics and modelling of the growth of white water floodplain. Unpubl. PhD Thesis, University of Göttingen.

Schöngart J. 2003b. Dendrochronologische Untersuchungen in Überschwemmungswäldern der várzea Zentralamazoniens. In: Böhnel, H., Tiessen, H. \& Weidelt, H. J. (eds.). Göttinger Beiträge zur Land- und Forstwirtschaft in den Tropen und Subtropen, Vol. 149. Göttingen.

Schöngart J., Junk W.J., Piedade M.T.F., Ayres J.M., Hüttermann A. \& Worbes M. 2004. Teleconnection between tree growth in the Amazonian Floodplains and the El Niño-Southern Oscillation Effect. Global Change Biology 10: 683-692

Schöngart J., Piedade M.F.T., Ludwigshausen S., Horna V. \& Worbes M. 2002. Phenology and stem-growth periodicity of tree species in Amazonian floodplain forests. Journal of Tropical Ecology 18: 581-597.

Wittmann F. \& Parolin P. (in press): Above-ground roots in Amazonian floodplain trees. Biotropica.

Wittmann F. 2002. Artenverbreitung und Bestandesstruktur in amazonischen Varzea-Wäldern und Möglichkeiten der Erfassung von Waldtypen mittels fernerkundlichen Methoden. PhD-Diss. Universität Mannheim.

Wittmann F., Anhuf D. \& Junk W.J. 2002. Tree species distribution and community structure of Central Amazonian várzea forests by remote sensing techniques. Journal of Tropical Ecology 18: 805820.

Worbes M. 1997. The forest ecosystem of the floodplains. In: The Central Amazon floodplain: Ecology of a pulsing system. Junk W.J. (ed.). Ecological Studies 126, Springer Verlag, Heidelberg.

\footnotetext{
1 Max-Planck-Institute for Limnology, Tropical Ecology Working Group, 24302 Plön, Germany; pparolin@mpil-ploen.mpg.de

${ }^{2}$ INPA/Max Planck, C.P. 478, 69011 Manaus, Am, Brasil.
} 